KATELYN M. MULLEN $(*)\left(^{\circ}\right)$ - SCOTT A. SCHNEIDER $(\dagger)(\#)-\operatorname{BENJAMIN~B.~NORMARK~}(*)(\dagger)$

\title{
NEW SINGLE-COPY NUCLEAR GENES FOR USE IN SCALE INSECT SYSTEMATICS $\left({ }^{1}\right)$
}

\author{
(*) Department of Biology and $\dagger$ Graduate Program in Ecology and Evolutionary Biology, University of Massachusetts \\ Amherst, Amherst, MA 01003, USA \\ (\#) present address: USDA, Agricultural Research Service, Henry A. Wallace Beltsville Agricultural Research Center, \\ Systematic Entomology Laboratory, 10300 Baltimore Avenue, Beltsville, MD, 20705, USA \\ $\left.{ }^{\circ}\right)$ Corresponding author: present address: Department of Chemistry and Chemical Biology, Harvard University. \\ kmullen@fas.harvard.edu
}

Mullen K.M., Schneider S.A., Normark B.B. - New single-copy nuclear genes for use in scale insect systematics.

Despite the advent of next-generation sequencing, the polymerase chain reaction (PCR) and Sanger sequencing remain useful tools for molecular identification and systematics. To date, molecular systematics of scale insects has been constrained by the paucity of loci that researchers have been able to amplify with available PCR primers. Due to the rapid molecular evolution of scale insects, "universal" primers, and even primers developed for their sister taxon the Aphidoidea, typically fail. We used transcriptome data for two diaspidids, Acutaspis umbonifera (Newstead) and Chrysomphalus aonidum (Linnaeus), together with a published aphid genome, to design novel PCR primer sets for scale insects. Our primers amplify fragments of eight single-copy genes: ATP-dependent RNA helicase (DHX8), translation initiation factor 5 (IF5X1), DNA replication licensing factor $(\mathrm{Mcm} 2)$, double-strand break repair protein (MRE11A), serine/threonineprotein phosphatase (PPP1CB), DNA-directed RNA polymerase II (RNApII), ribonucleoside-diphosphate reductase (RRM1), signal recognition particle receptor (SRP $\alpha$ ), neuronal PAS domain-containing protein 4 (NPAS4), and cleft lip and palate transmembrane protein 1 (TP1). Here we report the results of tests of amplification success and phylogenetic utility of these primer sets across the Diaspididae and nine other families of Coccomorpha.

KEY Words: molecular systematics, PCR primers, Coccomorpha, phylogenetics.

\section{INTRODUCTION}

Although whole-genome sequencing is becoming increasingly feasible in many systems, PCR and Sanger sequencing remain more-affordable workhorses for molecular systematics. However, for scale insects there are few loci for which PCR primer sets are available. Primer sequences have been published for only 7 nuclear loci: the large and small ribosomal subunits (18S, 28S), elongation factor 1-alpha (EF-1a), carbamoyl-phosphate synthetase (CAD), cytochrome oxidase I (COI) and cytochrome oxidase II (COII), triosphosphate isomerase, and dynamin (Gullan and COOK, 2007; Moulton and Wiegmann, 2004; HARDY, 2007; ANDERSEN et al., 2010); and of these, only a subset can be amplified for any given taxon, with only the ribosomal genes being consistently amplifiable. One of the reasons why molecular systematics of scale insects has been challenging is that there is a very long branch separating them from their sister taxon - the aphids indicating that a great deal of evolutionary change has occurred over a relatively short period of time (COOK et al., 2002). As a result of this divergence, primers that work for aphids and most other insects do not work well for scale insects. Using transcriptomes from two armored scale insects and an aphid, we designed primer sets for 10 loci, in the hope that they would be useful primarily in the Diaspididae and additionally across the Coccomorpha.

\footnotetext{
${ }^{1}$ Original scientific contribution presented and discussed at XIV International Symposium on Scale Insect Studies, Catania-Italy, 13-16 June 2016.
}

\section{MATERIALS AND METHODS}

PRIMER DESIGN

Two armored scale insect species, Acutaspis umbonifera (Newstead) and Chrysomphalus aonidum (Linnaeus), were collected from a greenhouse in Amherst, Massachusetts, and sent to Kevin Johnson at the University of Illinois Urbana-Champaign for transcriptome sequencing. Transcriptome data were filtered using the pipeline developed by GRANT and KATZ (2014) to only include contigs that were common to the two species. Primers for each gene were designed using the Primer3 software package (UNTERGASSER et al., 2012). Acyrthosiphon pisum transcriptome data were also used in the primer design process to determine whether primer sets could plausibly work for a wider range of taxa. These sequences were further aligned against a broad genomic dataset encompassing eukaryotes, archaea, and bacteria (GRANT and KATZ, 2014), resulting in approximately 600 candidate genes available for primer set design. Primers were designed to optimize PCR performance (APTE and DANIEL, 2009) and the best candidate primer pairs for 10 loci were tested on a set of scale insect taxa.

\section{TAXONOMIC SAMPLING}

PCR was attempted for 15 different families within the Coccomorpha for which DNA was available as of September 2014. We focused primarily on the Diaspididae because a majority of the specimens available to us belong to this family. Representatives from the Aphididae, Asterolecaniidae, Coccidae, Conchaspididae, Cryptococcidae, Eriococcidae, Kerriidae, Monophlebidae, Phoe- 
nicococcidae, Pseudococcidae and Stictococcidae were included as well. Any genes that were successfully sequenced for Acutaspis umbonifera were also attempted for 24 additional species within the Diaspididae. Amplification was attempted for 76 specimens (Table 1). The slide-mounted cuticles of all the specimens are deposited in the University of Massachusetts Insect Collection.

PCR AND SEQUENCING

DNA preparations of $A$. umbonifera were used to run initial gradient tests, to determine the ideal annealing temperature(s) for each primer set. With every PCR, this species was also used as a positive control to aid in interpreting the success of each reaction on the resulting gels. Primer sets and their corresponding PCR protocols are listed in Table 2. Nine gene fragments were used for molecular phylogenetic analysis: translation initiation factor 5 (IF5X1), 441 base pairs; DNA replication licensing factor $(\mathrm{Mcm} 2), 410 \mathrm{bp}$; double-strand break repair protein (MRE11A), 699 bp; serine/threonine-protein phosphatase (PPP1CB), 636 bp; DNA-directed RNA polymerase II
(RNApII), 657 bp; ribonucleoside-diphosphate reductase (RRM1), 863 bp; signal recognition particle receptor $(\mathrm{SRP} \alpha), 333 \mathrm{bp}$; cleft lip and palate transmembrane protein 1 (TP1), 473 bp; ATP-dependent RNA helicase (DHX8), multiple combinations of primers with different product sizes; and neuronal PAS domain-containing protein 4 (NPAS4), multiple combinations of primers with different product sizes.

Either Takara Ex Taq ${ }^{\circledR}$ hot-start polymerase (Clontech Laboratories, Inc., Mountain View, California) or GoTaq ${ }^{\circledR}$ G2 hot-start polymerase (Promega Corporation, Madison, Wisconsin) was used for standard PCR amplification. PCR protocols are listed in Table 1 . The presence and size of PCR products was determined using SYBR ${ }^{\circledR}$ Safe (Life Technologies, Carlsbad, California) ultraviolet stain and $1.5 \%$ agarose gel electrophoresis. PCR products were treated with Exonuclease I and Shrimp Alkaline Phosphatase (Affymetrix, Santa Clara, California) at $37^{\circ} \mathrm{C}$ for 25 minutes, followed by a cycle at $80^{\circ} \mathrm{C}$ for 15 minutes to denature any proteins. Purified PCR products were sent to the Genomics Resource Laboratory at the University of Massachusetts Amherst for Sanger sequencing using an ABI

Table 1 - Species for which amplification was attempted.

\begin{tabular}{|c|c|c|c|}
\hline Prep number & Species & Family & $\begin{array}{l}\text { Amplification } \\
\text { Success }\end{array}$ \\
\hline D0991A & undetermined sp. & Aphididae & yes \\
\hline D0991B & undetermined sp. & Aphididae & no \\
\hline D4189A & undetermined sp. & Aleyrodidae & no \\
\hline D2095A & Planchonia fimbriata (Boyer de Fonscolombe) & Asterolecaniidae & yes \\
\hline D4195A & undetermined sp. & Asterolecaniidae & yes \\
\hline D0320B & Bambusaspis miliaris (Boisduval) & Coccidae & yes \\
\hline D0328A & Ceroplastes rubens Maskell & Coccidae & yes \\
\hline D3008A & Conchaspis near lepagei & Conchaspididae & no \\
\hline D4355A & Conchaspis capensis (Linnaeus) & Conchaspididae & no \\
\hline $\mathrm{D} 0583 \mathrm{~F}$ & Cryptococcus fagisuga Lindinger & Cryptococcidae & yes \\
\hline D3089A & Acutaspis reniformis (Cockerell) & Diaspididae & yes \\
\hline D5045A & \multirow{6}{*}{ Acutaspis umbonifera (Newstead) } & \multirow{6}{*}{ Diaspididae } & \multirow{6}{*}{ yes } \\
\hline D5045B & & & \\
\hline D5045C & & & \\
\hline D5045D & & & \\
\hline D5045E & & & \\
\hline $\mathrm{D} 5045 \mathrm{~F}$ & & & \\
\hline D3400B & Aonidia lauri (Bouché) & Diaspididae & no \\
\hline D2052A & \multirow{2}{*}{ Aonidia paradoxa Lindinger } & \multirow{2}{*}{ Diaspididae } & \multirow{2}{*}{ yes } \\
\hline D2084A & & & \\
\hline D3286A & Aonidiella inornata McKenzie & Diaspididae & yes \\
\hline D3189A & Aspidaspis arctostaphyli (Cockerell \& Robbins) & Diaspididae & yes \\
\hline $\mathrm{D} 2727 \mathrm{~A}$ & Aspidaspis densiflorae (Bremner) & Diaspididae & yes \\
\hline D0955A & Aspidiella sacchari (Cockerell) & Diaspididae & yes \\
\hline D0703A & \multirow{2}{*}{ Aspidiotus destructor Signoret } & \multirow{2}{*}{ Diaspididae } & \multirow{2}{*}{ yes } \\
\hline D3045C & & & \\
\hline D3519C & Aspidiotus elaeidis Marchal & Diaspididae & yes \\
\hline D3536A & Aspidiotus fularum Balachowsky & Diaspididae & yes \\
\hline D0595A & \multirow{2}{*}{ Aspidiotus hedericola Leonardi } & \multirow{2}{*}{ Diaspididae } & \multirow{2}{*}{ yes } \\
\hline D0620A & & & \\
\hline D0103B & Aspidiotus nerii Bouché & Diaspididae & yes \\
\hline $\mathrm{D} 1876 \mathrm{E}$ & Affirmaspis cederbergensis Schneider & Diaspididae & yes \\
\hline D1540B & Chionaspis pinifoliae (Fitch) & Diaspididae & no \\
\hline D1538A & Chionaspis pinifoliae (Fitch) & Diaspididae & no \\
\hline
\end{tabular}


Continued Table 1

\begin{tabular}{|c|c|c|c|}
\hline Prep number & Species & Family & $\begin{array}{l}\text { Amplification } \\
\text { Success }\end{array}$ \\
\hline D1021A & Chrysomphalus aonidum (Linnaeus) & Diaspididae & no \\
\hline D2858B & Chrysomphalus aonidum (Linnaeus) & Diaspididae & yes \\
\hline D5044A & Chrysomphalus aonidum (Linnaeus) & Diaspididae & yes \\
\hline D5067A & Davidsonaspis aguacatae (Evans, Watson \& Miller) & Diaspididae & no \\
\hline D2706A & Diaspidiotus aesculi (Johnson) & Diaspididae & yes \\
\hline D1076A & \multirow{2}{*}{ Diaspidiotus ancylus (Putnam) } & \multirow{2}{*}{ Diaspididae } & \multirow{2}{*}{ yes } \\
\hline D1944A & & & \\
\hline D1108E & Diaspidiotus forbesi (Johnson) & Diaspididae & yes \\
\hline D1106E & Diaspidiotus liquidambaris (Kotinsky) & Diaspididae & yes \\
\hline D2756B & Diaspidiotus sulci (Balachowsky) & Diaspididae & yes \\
\hline D1401A & Dynaspidiotus britannicus (Newstead) & Diaspididae & yes \\
\hline D3035A & Hemiberlesia cyanophylli (Signoret) & Diaspididae & yes \\
\hline D2752A & Lepidosaphes ulmi (Linnaeus) & Diaspididae & no \\
\hline D0251D & Melanaspis obscura (Comstock) & Diaspididae & yes \\
\hline D1984B & Melanaspis smilacis (Comstock) & Diaspididae & yes \\
\hline D1888B & Melanaspis sp. & Diaspididae & no \\
\hline D3559A & Morganella conspicua (Brain) & Diaspididae & yes \\
\hline D3561A & Morganella conspicua (Brain) & Diaspididae & yes \\
\hline D3599A & Morganella conspicua (Brain) & Diaspididae & no \\
\hline D3619A & Morganella conspicua (Brain) & Diaspididae & yes \\
\hline D3146A & Oceanaspidiotus spinosus (Comstock) & Diaspididae & yes \\
\hline D4898A & Octaspidiotus stauntoniae (Takahashi) & Diaspididae & no \\
\hline D0281E & Prodigiaspis undescribed sp. & Diaspididae & yes \\
\hline D3642A & Pseudaulacaspis miyakoensis (Kuwana) & Diaspididae & no \\
\hline D3633A & Selenaspidus albus McKenzie & Diaspididae & no \\
\hline D3085A & Selenaspidus articulatus (Morgan) & Diaspididae & yes \\
\hline D1168E & undetermined sp. & Diaspididae & no \\
\hline D0037A & Eriococcus adenostornae Ehrhorn & Eriococcidae & yes \\
\hline D0074D & Pseudochermes fraxini (Kaltenbach) & Eriococcidae & yes \\
\hline D0787A & Ovaticoccus californicus McKenzie & Eriococcidae & yes \\
\hline D0333E & Paratachardina pseudolobata Kondo \& Gullen & Kerriidae & yes \\
\hline D0227C & Crypticerya brasiliensis (Hempel) & Monophlebidae & yes \\
\hline D3269B & Icerya purchasi Maskell & Monophlebidae & yes \\
\hline D1097C & undetermined sp. & Ortheziidae & no \\
\hline D4359B & Phoenicococcus marlatti Cockerell & Phoenicococcidae & yes \\
\hline D0588A & Pseudococcus longispinus Targioni Tozzetti & Pseudococcidae & yes \\
\hline D1142A & Planococcus citri Risso & Pseudococcidae & yes \\
\hline D4239A & undetermined sp. & Pseudococcidae & no \\
\hline D1894C & Myrmarachne formicaria (De Geer) & Salticidae & yes \\
\hline D3851A & Parastictococcus sp. & Stictococcidae & no \\
\hline D3854A & Stictococcus sp. & Stictococcidae & yes \\
\hline D3856A & Stictococcus vayssieri Richard & Stictococcidae & yes \\
\hline
\end{tabular}

Model 3130XL sequencer (Life Technologies, Carlsbad, California). For some genes where multiple products were amplified and the resulting sequences could not be aligned, internal sequencing primers were designed (Table 1). These PCR products were sequenced again with these internal sequencing primers.

The resulting DNA sequences were edited and aligned in Geneious 6.1.8 (Biomatters Limited, Auckland, New Zealand). Edited sequences were imported into Mesquite 3.04 (MADDISON and MADDISON, 2015) and aligned with MUSCLE (EDGAR 2004) for each locus. Alignments were further processed in PASTA 1.6.4 (MIRARAB et al., 2014). The default settings were maintained, using MAFFT as the aligner tool, MUSCLE as the merger, FASTTREE as the tree estimator, and GTR+G20 as the model. These settings were applied to SRPa, Mcm2, MRE11A, and RNApII for three iterations of tree estimation and re-alignment. We decided to focus our phylogenetic analyses on these four loci because they had the best sequencing success for $A$. umbonifera. The default job settings were also maintained, with the maximum subproblem set to $50 \%$ and decomposition set to centroid.

\section{Phylogenetic ANALYSES}

Three concatenated datasets were generated for phylogenetic analyses. The complete dataset contained all 42 taxa (30 species). Separate analyses were conducted for the new loci (RNApII, MRE11A, Mcm2, SRP $\alpha$ ) and the commonly used loci (28S, CAD, EF-1 $\alpha$ ), which contained the same 24 taxa ( 22 species). Both of the latter consensus 
Table 2 - PCR primers and protocols.

\begin{tabular}{|c|c|c|c|c|}
\hline Locus & Forward Primer & Reverse Primer & $\begin{array}{l}\text { Annealing Temperature } \\
\text { Protocol }\end{array}$ & $\begin{array}{l}\text { Families for which } \\
\text { amplification was successful }\end{array}$ \\
\hline $\mathrm{SRPa}$ & $\begin{array}{l}\text { SRPa 530F } \\
\text { 5' - ATG CRG CTG GAA } \\
\text { TTG CYA TGG AAG } \\
\text { C - 3' } \\
\text { Internal sequencing primer } \\
\text { SRPa 548intF } \\
\text { 5' - GGA ATT GCC ATG } \\
\text { GAA GCK AT - 3' }\end{array}$ & $\begin{array}{l}\text { SRPa } 863 R \\
\text { 5' - CC T GTG ATG TAT } \\
\text { GTC ATY GAW ATA } \\
\text { GC - 3' }\end{array}$ & $\begin{array}{l}58 \rightarrow 50^{\circ} \mathrm{C}\left(-1^{\circ} / 4 \text { cycles }\right) \\
+3 \text { cycles at } 50^{\circ} \mathrm{C} \text { for } 1 \\
\text { minute }\end{array}$ & $\begin{array}{l}\text { Aphididae, Asterolecaniidae, } \\
\text { Coccidae, Cryptococcidae, } \\
\text { Diaspididae, Eriococcidae, } \\
\text { Phoenicococcidae, Pseudococcidae }\end{array}$ \\
\hline RNApII & $\begin{array}{l}\text { RNApII_2519F } \\
\text { 5' - ATACGG CTG TGA } \\
\text { AAA CTG CTG A - 3', }\end{array}$ & $\begin{array}{l}\text { RNApII 3176R } \\
\text { 5' - CGA TCA ACC ATT } \\
\text { CAAACG CTT C - 3' }\end{array}$ & $\begin{array}{l}57 \rightarrow 51^{\circ} \mathrm{C}\left(-1^{\circ} / 3 \text { cycles }\right) \\
+15 \text { cycles at } 51^{\circ} \mathrm{C} \text { for } 1.5 \\
\text { minutes }\end{array}$ & $\begin{array}{l}\text { Coccidae, Diaspididae, } \\
\text { Pseudococcidae }\end{array}$ \\
\hline Mcm2 & $\begin{array}{l}\text { Mcm2 1333F } \\
\text { 5' - CCA GGT GAS AAA } \\
\text { CAT AAA MTY CGT } \\
\text { GG - 3' }\end{array}$ & $\begin{array}{l}\text { Mcm2 } 1743 \mathrm{R} \\
\text { 5' - RAA AGT CAT AGC } \\
\text { YGG ATC ATA SCG } \\
\text { WCC - 3' }\end{array}$ & $\begin{array}{l}58 \rightarrow 48^{\circ} \mathrm{C}\left(-1^{\circ} / 3 \text { cycles }\right) \\
+5 \text { cycles at } 48^{\circ} \mathrm{C} \text { for } 1 \\
\text { minute }\end{array}$ & Aphididae*, Diaspididae \\
\hline MRE11A & $\begin{array}{l}\text { MRE11A 42F } \\
\text { 5' - CGT AGC CAC TGA } \\
\text { TAT TCA TCT MGG - 3' }\end{array}$ & $\begin{array}{l}\text { MRE11A 741R } \\
\text { 5' - ACA CTC GTG TTC } \\
\text { GTG ACC C - 3' }\end{array}$ & $\begin{array}{l}57 \rightarrow 51^{\circ} \mathrm{C}\left(-1^{\circ} / 3 \text { cycles }\right) \\
+15 \text { cycles at } 51^{\circ} \mathrm{C} \text { for } 1.5 \\
\text { minutes }\end{array}$ & Diaspididae, Phoenicococcidae \\
\hline \multirow{2}{*}{ NPAS4 } & $\begin{array}{l}\text { NPAS4 19F } \\
\text { 5' - TTC TTG ATG } \\
\text { ATGATG ACG CA - 3, }\end{array}$ & $\begin{array}{l}\text { NPAS4 } 802 R \\
\text { 5' - GRA GTT TAC TYT } \\
\text { GCA CCA TGT - 3, }\end{array}$ & $\begin{array}{l}35 \text { cycles at } 48^{\circ} \mathrm{C} \text { for } 1.5 \\
\text { minutes }\end{array}$ & $\begin{array}{l}\text { Asterolecaniidae, Coccidae, } \\
\text { Diaspididae, Eriococcidae*, } \\
\text { Monophlebidae }\end{array}$ \\
\hline & $\begin{array}{l}\text { NPAS4 } 68 \mathrm{~F} \\
\text { 5' - AC GCC GCC GAA } \\
\text { TAC TTG G - 3' }\end{array}$ & $\begin{array}{l}\text { NPAS4 670R } \\
\text { 5' - CT TGT AGA ACG } \\
\text { CAR TGA ATC CA - 3' }\end{array}$ & $54 \rightarrow 52^{\circ} \mathrm{C}$ for 1 minute & Stictococcidae* \\
\hline \multirow{3}{*}{ IF5X1 } & \multirow{3}{*}{$\begin{array}{l}\text { IF5X1_29F } \\
\text { 5' - TCA GYG ATG CRT } \\
\text { TCT AYC GR - 3' }\end{array}$} & \multirow{3}{*}{$\begin{array}{l}\text { IF } 5 X 1 \text { 469R } \\
\text { 5' - ATG ATC CYT GAG } \\
\text { CKG CWG G - 3' }\end{array}$} & $\begin{array}{l}57 \rightarrow 51\left(-1^{\circ} / 3 \text { cycles }\right)+ \\
15 \text { cycles at } 51^{\circ} \mathrm{C} \text { for } 1.5 \\
\text { minutes }\end{array}$ & Cryptococcidae, Pseudococcidae \\
\hline & & & $\begin{array}{l}40 \text { cycles at } 51^{\circ} \mathrm{C} \text { for } 1 \\
\text { minute }\end{array}$ & Aphididae \\
\hline & & & $\begin{array}{l}40 \text { cycles at } 53^{\circ} \mathrm{C} \text { for } 1 \\
\text { minute }\end{array}$ & Phoenicococcidae, Diaspididae \\
\hline \multirow{3}{*}{ DHX8 } & \multirow{2}{*}{$\begin{array}{l}\text { DHX9 2F } \\
\text { 5'- GAC GGY ATG TTA } \\
\text { YTR CGW GA - 3' }\end{array}$} & $\begin{array}{l}\text { DHX8 2R } \\
\text { 5' - CMG GWA CAG } \\
\text { GHG TTG GTA AC - 3, }\end{array}$ & $\begin{array}{l}57 \rightarrow 51^{\circ} \mathrm{C}\left(-1^{\circ} / 3 \text { cycles }\right) \\
+15 \text { cycles at } 51^{\circ} \mathrm{C} \text { for } 1.5 \\
\text { minutes }\end{array}$ & $\begin{array}{l}\text { Coccidae, Eriococcidae, } \\
\text { Asterolecaniidae, Diaspididae }\end{array}$ \\
\hline & & $\begin{array}{l}\text { DHX8 1R } \\
\text { 5' - GGT ARW GCM } \\
\text { GAA TAY ACA GGW } \\
\text { A - 3' } \\
\end{array}$ & $\begin{array}{l}5 \text { cycles at } 45^{\circ} \mathrm{C} \text {, then } \\
49 \rightarrow 54^{\circ} \mathrm{C}\left(+1^{\circ} / 5 \text { cycles }\right) \\
\text { for } 1 \text { minute }\end{array}$ & Asterolecaniidae, Diaspididae \\
\hline & $\begin{array}{l}\text { DHX8 1041F } \\
\text { 5' - AAA CAR AGR GCT } \\
\text { GGT CGT GC - 3' }\end{array}$ & $\begin{array}{l}\text { DHX8 1340R } \\
\text { 5' - KGG AAA YTC TGC } \\
\text { CAT TCG TCT TCC - 3' }\end{array}$ & $\begin{array}{l}58 \rightarrow 48^{\circ} \mathrm{C}\left(-1^{\circ} / 3 \text { cycles }\right) \\
+5 \text { cycles at } 48^{\circ} \mathrm{C} \text { for } 1 \\
\text { minute }\end{array}$ & Asterolecaniidae* \\
\hline \multirow[b]{2}{*}{ RRM1 } & \multirow{2}{*}{$\begin{array}{l}\text { RRM1 } 2 \text { F } \\
\text { 5' - GGM AAA GTT GTB } \\
\text { GAA CGT C - 3' }\end{array}$} & \multirow{2}{*}{$\begin{array}{l}\text { RRM1_2R } \\
\text { 5' - TRC AWA CWG CTA } \\
\text { CYT CWT C - 3' }\end{array}$} & $\begin{array}{l}35 \text { cycles at } 49^{\circ} \mathrm{C} \text { for } 1 \\
\text { minute }\end{array}$ & $\begin{array}{l}\text { Coccidae, Kerriidae, } \\
\text { Monophlebidae }\end{array}$ \\
\hline & & & $\begin{array}{l}35 \text { cycles at } 48^{\circ} \mathrm{C} \text { for } 1 \\
\text { minute }\end{array}$ & $\begin{array}{l}\text { Asterolecaniidae, Cryptococcidae, } \\
\text { Diaspididae, Monophlebidae, } \\
\text { Pseudococcidae, Stictococcidae }\end{array}$ \\
\hline PPP1CB & $\begin{array}{l}\text { PPP1CB 198F } \\
\text { 5' - WTTATT TGA GTA } \\
\text { TGG AGG CTT TCC - 3, }\end{array}$ & $\begin{array}{l}\text { PPP1CB 834R } \\
5 \text { ' - RTCAAC AGA CAT } \\
\text { CAT WCC ACC WGC - } 3 \text {, }\end{array}$ & $\begin{array}{l}35 \text { cycles at } 54^{\circ} \mathrm{C} \text { for } 1 \\
\text { minute }\end{array}$ & Diaspididae, Phoenicococcidae \\
\hline \multirow[b]{2}{*}{ TP1 } & \multirow{2}{*}{$\begin{array}{l}\text { TP1 } 1 \text { 89F } \\
\text { 5' - AWM YYT CGA CCG } \\
\text { TTC ATG C - 3, }\end{array}$} & \multirow{2}{*}{$\begin{array}{l}\text { TP1 } 562 \mathrm{R} \\
\text { 5' - SRT CAT CWK CAT } \\
\text { CTG CAT CC - 3' }\end{array}$} & $\begin{array}{l}35 \text { cycles at } 49^{\circ} \mathrm{C} \text { for } 1 \\
\text { minute }\end{array}$ & Eriococcidae, Phoenicococcidae \\
\hline & & & $\begin{array}{l}5 \text { cycles at } 45^{\circ} \mathrm{C} \text {, then } \\
30 \text { cycles at } 52^{\circ} \mathrm{C} \text { for } 1 \\
\text { minute }\end{array}$ & Pseudococcidae \\
\hline
\end{tabular}

* Indicates families that have not been sequenced. Families represented reflect families that have been sequenced both successfully and unsuccessfully.

trees were compared to evaluate the performance of the new gene set against the set of commonly used loci. Each new gene region was also analyzed independently. No phylogenetic analyses were performed on NPAS4, IF5X1, DHX8, RRM1, PPP1CB, or TP1 due to a lack of successful sequencing for $A$. umbonifera, coupled with limited resources. The nucleotide sequence dataset was nearly complete for the standard set of loci - one taxon is missing data for $28 \mathrm{~S}$ and three taxa are missing data for EF-1 $\alpha$. Gaps in coverage are more severe across the new loci, which might reflect a need for further troubleshooting of PCR and/or sequencing protocols. The dataset for new loci is missing data for $33-45 \%$ of specimens.

Model selection analyses were run for each locus in 
jModelTest 2.1.7 (DARRIBA et al., 2012). For SRPa, RNApII, and MRE11A, the preferred evolutionary model is the Hasegawa-Kishino-Yano model (HKY), with a proportion of invariant sites and gamma-distributed rates $(\mathrm{HKY}+\mathrm{I}+\mathrm{G})$. For $\mathrm{Mcm} 2$ the preferred evolutionary model was also HKY, with a proportion of invariant sites $(\mathrm{HKY}+\mathrm{I})$. These preferred models were implemented in all subsequent analyses.

Bayesian inference using Metropolis-coupled Markov chain Monte Carlo (MC 3) methods were used in MrBayes 3.2.6 (RONQUIST and HUELSENBECK, 2003) to reconstruct a phylogeny of Coccomorpha specimens based upon DNA sequence data. Computational resources from Cyberinfrastructure for Phylogenetic Research (CIPRES) Science Gateway 3.3 (MiLLER et al., 2010) were used to complete these analyses. For each analysis, 2 independent runs were conducted concurrently with 4 chains each $(3$ hot, 1 cold). Each analysis of concatenated datasets was allowed to run for 10 million generations, sampling parameters every 1000 generations.

For the concatenated runs, stationarity was reached by 250 thousand generations as determined by visualizing the likelihood-by-generation plot, the potential scale reduction factor $(P S R F \cong 1.0)$, and the standard deviation of split frequencies $(\leq 0.01)$. The first $25 \%$ of generations were discarded as the burn-in, leaving a total of 7,501 trees from each run available for reconstruction of a majority-rule consensus tree. Consensus trees for each analysis were generated using the sumt command in MrBayes, providing branch lengths as substitutions per site and branch support values as posterior probabilities. Subsequent visual editing of the resulting trees was conducted in FigTree 1.4.2 (http://tree.bio.ed.ac.uk/software/figtree/). For independent genealogical analyses, the same methods as above were followed except that analyses were allowed to run for 5 million generations; the burn-in was also set to $25 \%$ of generations, leaving 3,751 trees from each run available for constructing each consensus tree. Genealogies were used to assess congruence of nodes on the concatenated majorityrule consensus trees for the new and standard loci.

\section{RESULTS}

PCR AMPLIFICATION AND SEQUENCING WITH NEW PRIMERS

All ten loci were successfully amplified for the Diaspididae. Table 2 gives a list of taxa for which at least one amplification was successful, as well as the number of specimens per species. Some PCR products were not sequenced, as indicated in Table 1. The most successful primer set designed was that for SRPa, which was successfully sequenced for 20 species representing five families across the Coccomorpha. However, successful sequencing required the use of an additional forward internal sequencing primer, and nearly half of the families sequenced with this aid (Asterolecaniidae, Cryptococcidae, and Pseudococcidae) still were not sequenced successfully, so there is room for improvement. RRM1 was very successful in amplifying for nine families across the Coccomorpha, but yielded low-quality sequence data even after utilizing internal sequencing primers.

\section{Phylogenetic ANALYSES}

Family-level relationships recovered from our analyses are largely inconsistent with previous studies of Coccomorpha phylogeny (COOK et al., 2002; GULLAN and CoOK, 2007). However, reconstructing a robust phylogeny of Coccomorpha was not a goal of this study and we hypothesize that the inconsistencies of higher-level relationships found are likely an artifact of incomplete character sampling. The careful studies of COOK et al. (2002) and GULLAN and COOK (2007) present a more reliable estimate of familylevel relationships among the Coccomorpha.

Focusing on relationships within Diaspididae (which relates more directly to the goals of this paper), we find relationships very closely matching expectations based upon previous studies (MORSE and NORMARK, 2006; ANDERSEN et al., 2010) and more recently completed work (SCHNEIDER et $a l$., in prep) (Fig. I). A strongly-supported ( $\mathrm{pp}=1.0)$ monophyletic clade of "core aspidiotines", sensu ANDERSEN et al. (2010), is recovered in our analysis (Fig. I). The clade representing multiple Diaspidiotus species and close relatives and the clade including Aspidiotus nerii and its relatives, are consistent with previous results (SCHNEIDER et al., in prep). We also find that the addition of new loci helps to further resolve relationships that have either proven difficult to resolve in previous efforts or have yielded different results. For example, recent phylogenetic reconstructions of Diaspididae recover Aspidiotus hedericola as sister to the tribe Aspidiotini (SCHNEIDER et al., in prep), but our results recover this species nested within a Palearctic/Afrotropical clade of Aspidiotus and Selenaspidus species with weak support (posterior probability $=0.86$, Figure I). The position of the South African species Aspidiotus elaeidis and A. fularum as a part of this Afrotropical/Palearctic clade is unique to this analysis. The previously indeterminate placement of Selenaspidus articulatus was resolved as sister to the latter clade with weak support (posterior probability $=0.69$, Fig. I).

The juxtaposed majority-rule consensus trees resulting from independent analyses of standard vs. new loci (1 and $\mathbf{2}$ respectively - Fig. II) show how the two sets of loci are congruent in some clades and differ - either in resolution or composition - in others. Even with a higher degree of missing data, the new set of loci $(2-$ Fig. II) recover the same relationships as the standard set $(\mathbf{1}-$ Fig. II $)$ for the Diaspidiotus + relatives clade mentioned above. Aspidiella sacchari, Oceanaspidiotus spinosus and Aspidiotus destructor are recovered with the same relationships in both as well. The Melanaspis species are found to be more closely related to $A$. nerii + relatives in $\mathbf{1}$, and more closely related to Selenaspidus in 2 (Fig. II). Take note that Melanaspis smilacis is missing a large amount of character data, which could account for its equivocal position in 2(Figure II). The full dataset analysis (Fig. I) is consistent with the results of 2 (Fig. II) in this respect, showing Melanaspis + Acutaspis as sister to the Afrotropical/Palearctic clade - albeit weakly supported $(\mathrm{pp}=$ 0.66 , Fig. I). Aspidiotus hedericola is positioned as sister to the rest of the aspidiotine species in 1; its position is unresolved in 2. The resolution of $A$. elaeidis + A. fularum is improved in 2, and is recovered as sister to Selenaspidus + Melanaspis.

\section{DISCUSSION}

Our analyses suggest that SRP $\alpha$, RNApII, Mcm2, and MRE11A may serve as informative genes for phylogenetic reconstruction of the Diaspididae. Great advances in our understanding of diaspidid phylogenetic relationships have been made using data from 28S, EF-1a, COI-COII, and CAD (Morse and Normark 2006; ANDERSEN et al., 2010; SCHNEIDER et al., in prep). 


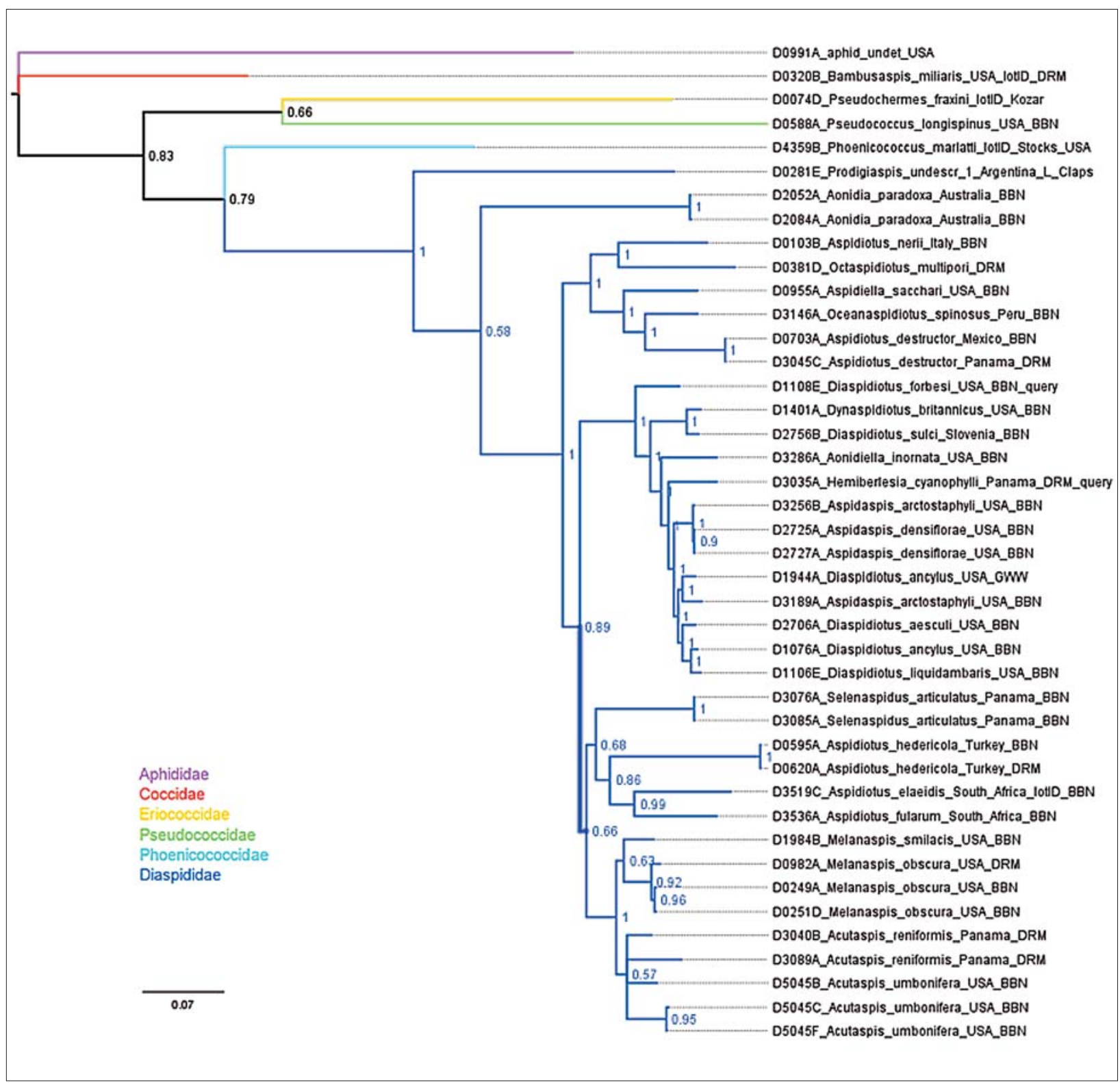

Fig. I - Phylogeny of the superfamily Coccomorpha. The majority-rule consensus tree resulting from Bayesian analysis of the concatenated dataset for seven gene regions (28S, EF-1 $\alpha$, CAD, SRP $\alpha$, RNApII, Mcm2, MRE11A) of 42 taxa (30 species). Taxa are listed as: Identification \# (e.g. D0991A)_Species name_Locality_Identifier. The specimen designated as "undescr" is an undescribed new species of Prodigiaspis. Branch support values are indicated as posterior probabilities. Families are color coded by branch as indicated by the legend.

Our newly developed primer sets demonstrate great potential for continuing this work. SRP $\alpha$, RNApII, Mcm2, and MRE11A add new information to the phylogeny that can help address outstanding questions about relationships between diaspidids. For instance, Aspidiotus hedericola was recovered as part of a Palearctic/Afrotropical clade nested within Aspidiotini, rather than as sister to the rest of Aspidiotini as has been found previously (SCHNEIDER et al., in prep).

In addition to the four primer sets we used to reconstruct a phylogeny of species from Coccomorpha (SRPa, RNApII, Mcm2, MRE11A), we lay the groundwork for potentially incorporating six additional loci in such analyses. The relative sequencing success of IF $5 X 1$, DHX8, TP1, PPP1CB, NPAS4, and RRM1, as well as details regarding which families each primer set worked for, are provided as a starting point for continuation of this work.

\section{ACKNOWLEDGEMENTS}

We thank everyone who has provided specimens, including Lucia Claps, Jan Giliomee, George Japoshvili, Gillian Watson, Takumasa Kondo, Dug Miller, and Armand Doumtsop. Kevin Johnson at University of Illinois, UrbanaChampaign provided transcriptome data from Acutaspis umbonifera and Chrysomphalus aonidum, which were then filtered by Kim Walden to only include contigs that were common between the transcriptome results for both diaspidid species. Laura Katz of Smith College provided transcriptome contigs for Acyrthosiphon pisum and several other insect species, which were processed by Jessica Grant. We thank the reviewers for providing helpful comments on an earlier version of this manuscript. This research was supported by NSF (DEB-0447880), the National Institute for Food and Agriculture, and the Massachusetts 
(1) 28S, EF-1a, CAD

D0281E_Prociglaspls_undescr_1_Argentina_ßotID_L_Claps

D2052A_Aonidia_paradoxa_Australia_BBN

D0595A_Aspidiotus_hedericola_Turkey_B8N

D0620A_Aspldiotus_hedericola_Turkey_DRM

D3085A_Selenaspidus_articulatus_Panama_BBN - D3519C_Aspidiotus_elaeidis_South_Africa_lotID_BBN 03536A_Aspidiolus_fularum_South_Africa_88N

D0251D_Melanaspls_obscura_USA_BBN D1984B_Melanaspis_smilacis_USA_BBN 0.89 .99 D0103B_Aspridiotus_nerii_ttaly_BBN - DOS55A_Aspidictia_sacchari_USA_BBN D3146A_Oceanaspidiotus_spinosus_Peru_BBN D0703A_Aspidiotus_destructor_Mexico_BBN D3045C_Aspidiotus_destructor_Panama_DRM

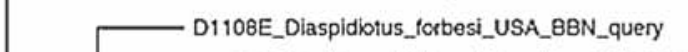
- D1401A_Dynaspidiotus_britannicus_USA_BBN $1-\left[\begin{array}{l}1 \\ \text { D2756B_Diaspidiotus_sulci_Slovenia_BBN }\end{array}\right.$ 1 - D3286A_Aonidiolla_inornata_USA_BBN 1_ D3035A_Herriberlesia_Cyanophya_Panama_DRM_query p.95-D2727A_Aspidaspis_densitlorae_USA_BBN 0.7802706A_Diaspiciotus_aesculi_USA_BBN $[0.71$ D1076A_Diaspldiotus_ancylus_USA_BBN 1 D1106E_Diaspidiotus_liquidambaris_USA_B8N

- D0281E_Prodiginspis_undescr_1_Argentina_lotID_L_Claps

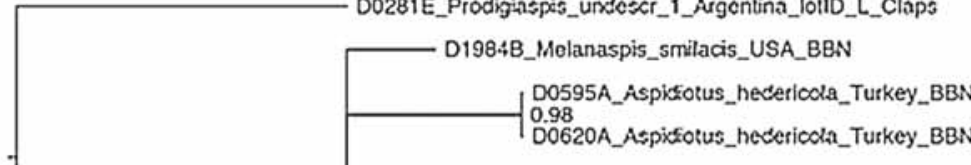
0.83 D2052A_Acnidia_paradoxa_Austratia_BBN

DOSS5A_Aspidiolta_sacchari_USA_B8N 0.62 D3146A_Oceanaspidiotus_spinosus_Peru_B8N D0703A_Aspidiotus_destructor_Mexico_egN D3045C_Aspidiotus_destructor_Panama_DAM

O03085A_Selenaspidus_articulatus_Panama_BBN

0.62 D3085A_Selenaspidus_articulatus_Panama_BBN
0.54 D3519C_Aspldiotus_elaeldis_Scuth_Atrica_lotID_BBN
D3536A_Aspidiotus_fularum_Scuth_Atrica_BBN
1 D1401A_Dynaspldiotus_britannicus_USA_BBN

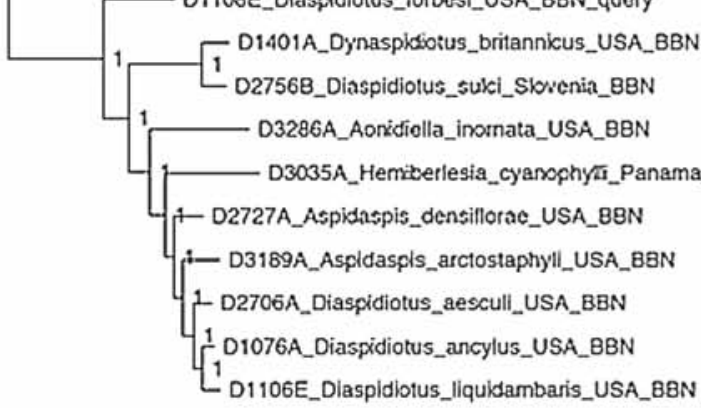

Fig. II - Majority-rule consensus trees of standard (1) vs. new (2) loci. These trees resulted from Bayesian analysis of the concatenated datasets for (1) three gene regions (28S, EF-1 $\alpha$, CAD) of 24 taxa (22 species) and for (2) four gene regions (SRPa, Mcm2, MRE11A, RNApII) of 34 taxa (29 species). Taxa are listed as: Identification \# (e.g. D0991A)_Species name_Locality_Identifier. The specimen designated as "undescr" is an undescribed new species of Prodigiaspis. Branch support values are indicated as posterior probabilities. 
Agricultural Experiment Station (Hatch MAS00452). Mention of trade names or commercial products in this publication is solely for the purpose of providing specific information and does not imply recommendation or endorsement by the U.S. Department of Agriculture; USDA is an equal opportunity provider and employer.

\section{REFERENCES}

Andersen J.C., Wu J., Gruwell M.E., Gwiazdowski R., Santana S.E., Feliciano N.M., Morse G.E., Normark B.B., 2010 - A phylogenetic analysis of armored scale insects (Hemiptera: Diaspididae), based upon nuclear, mitochondrial, and endosymbiont gene sequences - Mol. Phylogenet. Evol., 57 (3): 992-1003.

Apte A., Daniel S., 2009 - PCR primer design. Cold Spring Harbor Protocols, 3: pdb-ip65.

Cook L.G., Gullan P.J., Trueman H.E., 2002 - A preliminary phylogeny of the scale insects (Hemiptera: Sternorrhyncha: Coccoidea) based on nuclear small-subunit ribosomal DNA. - Mol. Phylogenet. Evol., 25 (1): 43-52.

Darriba D., Taboada G.L., Doallo R., Posada D., 2012 jModelTest 2: more models, new heuristics and parallel computing. - Nat. Methods, 9 (8): 772.

GRANT J.R., KATZ L.A., 2014 - Building a phylogenomic pipeline for the eukaryotic tree of life - addressing deep phylogenies with genome-scale data. - PLoS Currents Tree of Life, 1.

Gullan P.J., Cook L.G., 2007 - Phylogeny and higher classification of the scale insects (Hemiptera: Sternorrhyncha: Coccoidea). - Zootaxa, 1668: 413-425.
Hardy N.B., 2007 - Phylogenetic utility of dynamin and triose phosphate. - Zootaxa, 1668: 413-425.

MADDISON W.P., MADDISON D.R., 2015 - Mesquite: a modular system for evolutionary analysis - Version 3.04. http://mesquiteproject.org.

Miller M.A., Pfeiffer, W., Schwartz, T., 2010 - Creating the CIPRES Science Gateway for inference of large phylogenetic trees. In: Proceedings of the Gateway Computing Environments Workshop (GCE), 14 Nov. 2010, New Orleans, LA pp 1-8.

Mirarab S., Nguyen N., Warnow T., 2014 - PASTA: ultra-large multiple sequence alignment. In: International Conference on Research in Computational Molecular Biology, Springer International Publishing, Switzerland, pp. 177-191.

Morse G.E., Normark B.B., 2006 - A molecular phylogenetic study of armoured scale insects (Hemiptera: Diaspididae). - Syst. Entomol., 31: 338-349.

Moulton J.K., WiEgmann B.M., 2004 - Evolution and phylogenetic utility of CAD (rudimentary) among Mesozoic-aged Eremoneuran Diptera (Insecta). - Mol. Phylogenet. Evol, 31: 363-378.

Ronquist F., Huelsenbeck J.P., 2003 - MrBayes 3: Bayesian phylogenetic inference under mixed models. Bioinformatics, 19(12): 1572-1574.

Ungergasser A., Cutcutache I., Koressaar T., Ye J., FAircloth B.C., Remm M., Rozen S.G., 2012 - Primer3 - new capabilities and interfaces. - Nucleic Acids Research, 40: e115. 